A) Check for updates

Cite this: Org. Biomol. Chem., 2017, 15, 7227

Received 19th June 2017,

Accepted 7th August 2017

DOI: $10.1039 / c 7 o b 01478 c$

rsc.li/obc

\section{Palladium-catalyzed allylic amination: a powerful tool for the enantioselective synthesis of acyclic nucleoside phosphonates $\uparrow$}

\author{
Mariam Azzouz, Sébastien Soriano, Margarita Escudero-Casao, (iD \\ M. Isabel Matheu, (D) Sergio Castillón (D) * and Yolanda Díaz (DD*
}

Acyclic nucleoside phosphonates have been prepared in a straightforward manner and in high yields by an enantioselective palladium-catalyzed allylic substitution involving nucleic bases as nucleophiles followed by cross-metathesis reaction with diethyl allylphosphonate.

\section{Introduction}

Acyclic nucleoside phosphonates (ANPs) ${ }^{1}$ belong to a family of modified nucleoside analogues, in which the sugar moiety has been replaced by a functionalized acyclic chain linking the nucleobase at one end and the phosphonic acid group at the other. Relevant ANPs that have been pursued as antiviral agents are cidofovir (HPMPC), adefovir (PMEA), and tenofovir ${ }^{2}$ (PMPA) (Fig. 1). Because of their limited oral bioavailability, the last two compounds have been converted to their oral prodrug forms, adefovir dipivoxil or bis(pivaloyloxymethyl)-
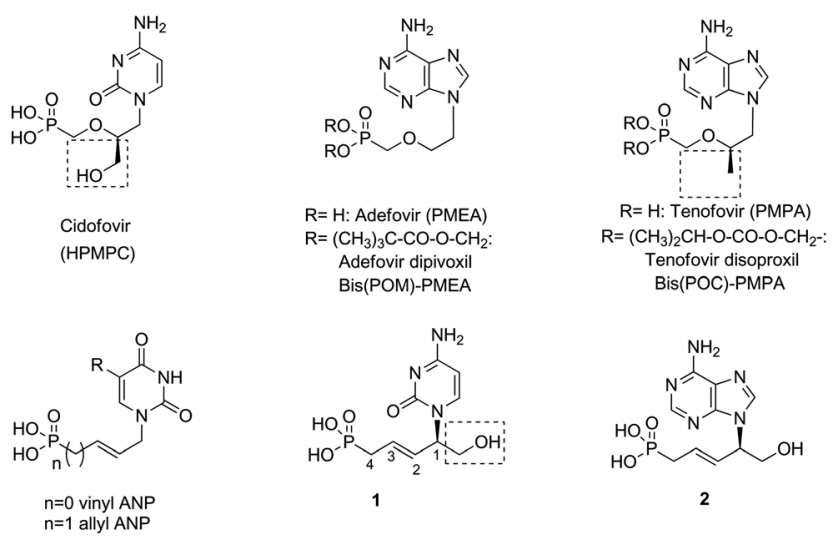

Fig. 1 Relevant reported ANPs and products 1 and 2 described in this paper.

Departament de Quimica Analitica I Quimica Orgànica, Facultat de Quimica, Universitat Rovira i Virgili, C/Marcel-lí Domingo 1, 43007 Tarragona, Spain. E-mail: yolanda.diaz@urv.cat, sergio.castillon@urv.cat

$\dagger$ Electronic supplementary information (ESI) available: ${ }^{1} \mathrm{H}$ and ${ }^{13} \mathrm{C}$ NMR and HPLC traces of reported products. See DOI: $10.1039 / \mathrm{c} 7 \mathrm{ob} 01478 \mathrm{c}$
PMEA [bis(POM)-PMEA] and tenofovir disoproxil or bis(isopropyloxycarbonyloxymethyl)-PMPA [bis(POC)-PMPA], respectively. Many analogues of these compounds have been prepared incorporating modifications in the base, alkyl chain or in the phosphonate moiety. Examples of modification in the alkyl chain are vinyl and allyl ANPs, where a $\mathrm{CH}_{2}$ group replaces the oxygen of the ether function in the alkyl chain (Fig. 1). ${ }^{3}$

Acyclic nucleosides are commonly synthesized from nucleic bases and chiral starting materials by alkylation, Mitsunobu reaction, epoxide opening, ${ }^{4}$ and by silver-catalyzed addition of different nucleophiles to 9-allenyl-9H-purines. ${ }^{5}$ The reported asymmetric synthesis of acyclic nucleosides involves the transition metal- ${ }^{6}$ or organocatalyzed $^{7}$ aza-Michael reaction of purinic bases to acrylates and asymmetric hydrogenation of purine-substituted acrylates. ${ }^{2}$

Allylic substitution has also been used in the synthesis of acyclic nucleosides to provide compounds with the nucleic base linked to the terminal carbon. ${ }^{8}$ Hartwig recently reported an enantioselective allylic amination using an iridium catalyst to afford acyclic nucleosides where the nucleic base is bonded to a stereocenter. ${ }^{9}$ Trost described the desymmetrization of meso 1,4-cyclopentenyl-dibenzoate derivatives using palladium-DACH catalysts in a straightforward synthesis of carbocyclic nucleosides. ${ }^{10}$ He found that the use of nucleobases as nucleophiles has a remarkable effect on the catalytic turnover and the enantioselectivity of desymmetrization reactions. ${ }^{9}$ Furthermore, Pd-catalyzed DYKAT of vinyl epoxide $\mathbf{4}$ is an efficient procedure for preparing 2-amino-3-buten-1-ol derivatives, ${ }^{11}$ which are attractive intermediates for synthesizing acyclic nucleosides, although for this purpose it will be necessary to explore the behavior of the different nucleic bases in the reaction. Recently, we have demonstrated that allyl carbonate $\mathbf{5}$, substituted with a hydroxymethyl group, is an appropriate substrate for the Pd-catalyzed asymmetric allylic amination reaction (Pd-AAA), affording the branched derivative with high 


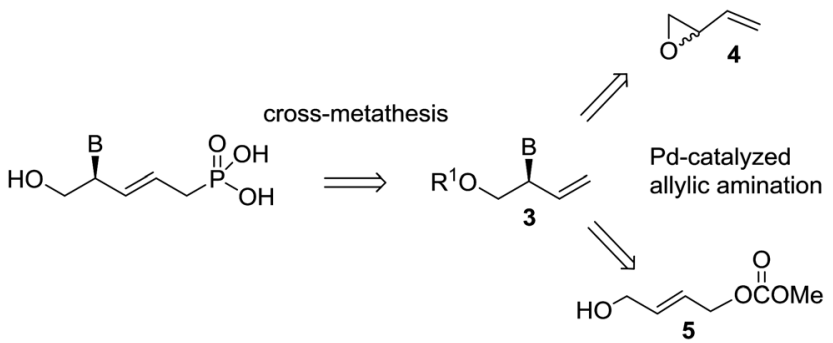

Scheme 1 Retrosynthesis of ANPs 1 and 2.

regio- and enantioselectivities. ${ }^{12}$ In this regard, quite a striking different regioselectivity in the reaction of substrates $\mathbf{4}$ and $\mathbf{5}$ with amines was observed, with epoxide 4 furnishing equimolar mixtures of linear and branched aminated products. In this work, we report a comparative study of the Pd-catalyzed asymmetric allylic amination reaction starting from vinylepoxide 4 and carbonate 5 with different nucleic bases, and we show that the resulting derivatives 3 can be transformed into novel ANP nucleosides $(\mathbf{1}, \mathbf{2})$, structurally related to cidofovir, tenofovir and to allyl ANP (Scheme 1). We have also extended this synthesis to the guanine precursor $\mathbf{1 0}$ (see Scheme 2).

\section{Results and discussion}

Preliminary assays starting from vinyl epoxide $\mathbf{4}$ and acetylcytosine under reaction conditions optimized in a previous study $^{12} \quad$ (6 mol\% $(R, R)$-DACH-naphthyl Trost ligand and $2 \mathrm{~mol} \%\left[\mathrm{Pd}\left(\eta^{3}-\mathrm{C}_{3} \mathrm{H}_{5}\right) \mathrm{Cl}\right]_{2}$ as a catalytic system in $\mathrm{CH}_{2} \mathrm{Cl}_{2}$, at room temperature), led to the formation of a bis-allylation product containing the 3-buten-1-ol-2-yl units at position 1 and at the exocyclic NH group. This compound was obtained even by reducing the amount of acetylcytosine to 1.1 equivalents. We therefore turned our attention towards di-Boccytosine (6a). ${ }^{13}$ When the reaction was conducted under similar conditions using epoxide $\mathbf{4}$ and di-Boc-cytosine (6a), branched product 7 a was obtained in $81 \%$ yield and $62 \%$ ee (Table 1, entry 1). Decreasing the temperature to $0{ }^{\circ} \mathrm{C}$ did not practically improve the enantioselectivity, while conducting the reaction at $35{ }^{\circ} \mathrm{C}$ eroded the enantioselectivity significantly (Table 1, entries 2 and 3). The analogous reaction of carbonate 5 with di-Boc-cytosine (6a) using the $(S, S)$ ligand (Table 1, entry 4) furnished the enantiomer ent-7a in 92\% yield and $73 \%$ ee. Interesting enough, all reactions from both 4 and 5 were highly regioselective affording exclusively the branched isomer. The use of BSA-KOAc did not improve the results. Lowering the temperature to $0{ }^{\circ} \mathrm{C}$ did not improve the enantioselectivity (Table 1, entry 5). Further optimization was focused on the precatalyst loading: a reduction from $2 \mathrm{~mol} \%$ to $1 \mathrm{~mol} \%$ produced a drastic decrease in the enantioselectivity (Table 1, entry 6), while an increase in the precatalyst loading to $3 \mathrm{~mol} \%$ did not provide significant improvement (result not shown in the table). In this context, we selected room tempera-
Table 1 Allylic amination of epoxide 4 or carbonate 5 with cytosine derivative $6 \mathrm{a}$ affording $7 \mathrm{a}$ using $\mathrm{Pd} / \mathrm{DACH}$-naphthyl ligand as catalytic system ${ }^{a}$

\begin{tabular}{|c|c|c|c|c|c|}
\hline & $\curvearrowright_{5} \mathrm{ococ}$ & Boc & $\begin{array}{c}(R, R) \text { DACh } \\
\text { Trost li } \\
\mathrm{CH}_{2} \mathrm{~mol} \% \eta^{3}\end{array}$ & $\underset{{ }_{5} \mathrm{Cl}_{2}}{\longrightarrow}$ & $\hat{S}_{N}^{N-B o c}$ \\
\hline Entry & $\begin{array}{l}\text { Starting } \\
\text { material }\end{array}$ & $T\left({ }^{\circ} \mathrm{C}\right)$ & 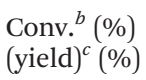 & $\mathrm{ee}^{d}(\%)$ & Product $^{e}$ \\
\hline $1^{f}$ & 4 & $\mathrm{rt}$ & $>98(81)$ & 62 & $7 \mathbf{a}$ \\
\hline $2^{f}$ & 4 & 0 & $>98(85)$ & 65 & $7 a$ \\
\hline $3^{f}$ & 4 & 35 & $>98(81)$ & 32 & $7 a$ \\
\hline $4^{g}$ & 5 & $\mathrm{rt}$ & $>98(92)$ & 73 & ent-7a \\
\hline $5^{g}$ & 5 & 0 & $>98(90)$ & 75 & ent-7a \\
\hline $6^{g, h}$ & 5 & $\mathrm{rt}$ & $>98(90)$ & 42 & ent-7a \\
\hline
\end{tabular}

${ }^{a}$ Conditions: $\left[\mathrm{Pd}\left(\eta^{3}-\mathrm{C}_{3} \mathrm{H}_{5}\right) \mathrm{Cl}\right]_{2}(2 \mathrm{~mol} \%)$, naphthyl ligand (6 mol\%), substrate (1 equiv.), nucleophile ( 2 equiv.). Reaction time $=16 \mathrm{~h}$. Concentration $=0.02 \mathrm{M}$ in $\mathrm{CH}_{2} \mathrm{Cl}_{2} \cdot{ }^{b} \mathrm{~A}$ branched/linear ratio $>98:<2$ was observed in all cases. ${ }^{c}$ Isolated yield of branched regioisomer. ${ }^{d}$ Determined by HPLC on a DAICEL CHIRALCEL OD-H column. ${ }^{e}$ The absolute configurations of the products were established by analogy with those obtained by Trost using phthalimide as analogous soft $N$-nucleophiles to nucleic bases (ref. 11a). ${ }^{f}$ The $(R, R)$-naphthyl ligand was used. ${ }^{g}$ The $(S, S)$-naphthyl ligand was used. ${ }^{h} 1 \mathrm{~mol} \%\left[\mathrm{Pd}\left(\eta^{3}-\mathrm{C}_{3} \mathrm{H}_{5}\right)\right.$ $\mathrm{Cl}]_{2}$ was used.

ture and $2 \mathrm{~mol} \%$ of the palladium precursor as standard reaction conditions.

It can be concluded from Table 1 that, in analogy to reaction from vinyl epoxide 4, Pd-AAA from carbonate 5 with diBoc-cytosine (6a) using the $\left[\mathrm{Pd}\left(\eta^{3}-\mathrm{C}_{3} \mathrm{H}_{5}\right) \mathrm{Cl}\right]_{2} / \mathrm{DACH}$-naphthyl ligand as the catalytic system provides good yields of the branched aminated product 7a/ent-7a in complete regioselectivity and moderate enantioselectivity. We therefore decided to extend this comparative study to other purinic bases. The results are collected in Table 2 .

Di-Boc-adenosine $(\mathbf{6 b})$ reacted with epoxide 4 in the presence of the $(R, R)-\mathrm{DACH}$-naphthyl ligand to provide $7 \mathbf{b}$ in an excellent yield of $92 \%$ and $92 \%$ ee (entry 2 ). When the reaction was conducted with carbonate 5 using the $(S, S)-\mathrm{DACH}-$ naphthyl ligand, ent-7b was obtained in an excellent yield of $92 \%$ and $88 \%$ ee (entry 2 ).

6-Chloropurine (6c) is a versatile starting material in nucleoside synthesis since it allows a set of useful and wellknown transformations for the synthesis of nucleoside derivatives. When carbonate $\mathbf{5}$ was treated with $\mathbf{6 c}$ in the presence of the $(S, S)$-DACH-naphthyl ligand under the standard conditions, compound ent-7c was obtained in very good $91 \%$ enantioselectivity, slightly higher than that obtained from $\mathbf{6 b}$ (Table 2, entry $2 v s$. 4). Pd-AAA of $6 \mathrm{c}$ from epoxide 4 furnished the allylated purine $\boldsymbol{e n t}$-7c with almost the same enantioselectivity of that obtained from $\mathbf{6 b}$ (Table 2, entry 1 vs. 3). 
Table 2 Palladium-catalyzed allylic amination reaction of epoxide 4 or carbonate 5 with pyrimidinic and purinic bases $6 b-e^{a}$

\begin{tabular}{|c|c|c|c|c|c|}
\hline & 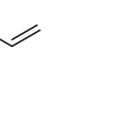 & $\begin{array}{l}\mathrm{Nu}-\mathrm{H} \\
\text { 6b-d }\end{array}$ & $\begin{array}{r}{\left[\mathrm{Pd}\left(\eta_{3}-\mathrm{C}_{3} \mathrm{H}_{5}\right)\right.} \\
\text { DACH-naphthyl } \\
\mathrm{CH}_{2} \mathrm{Cl}_{2}, \mathrm{rt}\end{array}$ & $\stackrel{\text { and }}{\longrightarrow}$ & $\overbrace{b-d}^{N u}$ \\
\hline & & & & & \\
\hline Entry & $\begin{array}{l}\text { Starting } \\
\text { material }\end{array}$ & $\begin{array}{l}\text { Nucleic } \\
\text { base }\end{array}$ & Product $^{b}$ & $\begin{array}{l}\text { Conv. }{ }^{c} \\
\text { (yield) }^{d}\end{array}$ & $\mathrm{ee}^{e}(\%)$ \\
\hline $1^{f}$ & 4 & $6 \mathrm{~b}$ & $7 \mathbf{b}$ & $>98(92)$ & 92 \\
\hline $2^{g}$ & 5 & $6 \mathrm{~b}$ & ent-7b & $>98(92)$ & 88 \\
\hline $3^{g}$ & 4 & $6 c$ & ent-7c & >98 (89) & 91.4 \\
\hline $4^{g}$ & 5 & $6 c$ & ent-7c & $>98$ (96) & 91 \\
\hline $5^{g}$ & 4 & $6 d$ & ent-7d & $>98(89)$ & 88 \\
\hline $6^{g}$ & 5 & $6 d$ & ent-7d & $>98(92)$ & 88 \\
\hline $7^{f}$ & 4 & $6 e$ & $7 e$ & 31 (19) & 90 \\
\hline $8^{f}$ & $4^{h}$ & $6 e$ & $7 e$ & $>98(64)$ & 90 \\
\hline $9^{f}$ & 5 & $6 e$ & $7 e$ & $72(43)$ & 92 \\
\hline
\end{tabular}

${ }^{a}$ Conditions: $\quad\left[\mathrm{Pd}\left(\eta^{3}-\mathrm{C}_{3} \mathrm{H}_{5}\right) \mathrm{Cl}\right]_{2} \quad(2 \mathrm{~mol} \%)$, DACH-naphthyl ligand (6 mol\%), substrate (1 equiv.), nucleophile (2 equiv.), rt, $16 \mathrm{~h}$. Substrate concentration $=0.02 \mathrm{M} .{ }^{b}$ The absolute configurations of the products were established by analogy with those obtained by Trost using phthalimide as analogous soft $N$-nucleophiles to nucleic bases (ref. $11 a$ ). ${ }^{c} \mathrm{~A}$ branched/linear ratio $>98:<2$ was observed in all cases by ${ }^{1} \mathrm{H}$ NMR spectroscopy of the crude products. ${ }^{d}$ Isolated yield of the branched regioisomer. ${ }^{e}$ Determined by HPLC on a DAICEL CHIRALCEL OD-H column. ${ }^{f}(R, R)$-DACH-naphthyl ligand was used. ${ }^{g}(S, S)$-DACH-naphthyl ligand was used. ${ }^{h} \mathrm{Using}\left[\mathrm{Pd}\left(\eta^{3}-\mathrm{C}_{3} \mathrm{H}_{5}\right) \mathrm{Cl}\right]_{2}$ (2 mol\%), DACH-naphthyl ligand (6 mol\%), substrate (2 equiv.), nucleophile (1 equiv.), rt, 16 h. Substrate concentration $=0.04 \mathrm{M}$.

Furthermore, the reaction of epoxide $\mathbf{4}$ and carbonate $\mathbf{5}$ with benzimidazole (6d) as a nucleophile using the $(S, S)$ DACH-naphthyl ligand, afforded compound ent-7d in good yields and the same enantioselectivity, (88\% ee) (Table 2, entries 5 and 6).

Di-Boc-2-amino-6-chloropurine 6 e reacted with epoxide 4 and carbonate $\mathbf{5}$ under standard conditions to provide $\mathbf{7 e}$ with high enantioselectivity but with low to moderate yields (Table 2, entries 7 and 9). However, on inverting the reaction stoichiometry a substantial improvement in the yield was achieved (64\%) with the same enantio-induction (Table 2, entry 8 ).

Contrary to their complementary behavior in terms of regioselectivity observed with hard amine nucleophiles, ${ }^{12}$ both epoxide $\mathbf{4}$ and carbonate $\mathbf{5}$ afforded valuable branched products with high degrees of enantioselectivity when reacting with nucleobases. The regioselectivity observed in the reactions of epoxide $\mathbf{4}$ with nucleobases is comparable to that already observed with other soft nitrogen nucleophiles, such as imides or imidocarboxylates, as a result of a dynamic kinetic asymmetric transformation. As for carbonate 5, the branched regioisomer is always observed as a major product, regardless of the nitrogen nucleophile used, due to an enantioselective Pd-allylic amination, where hydrogen bonding inter-
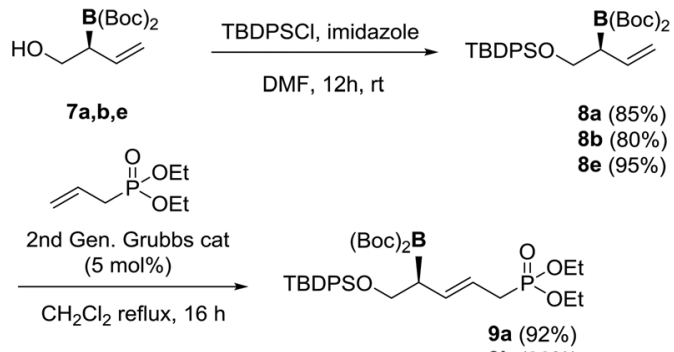

9a $(92 \%)$

9b $(90 \%)$
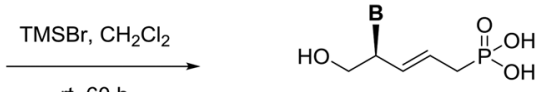

$1 \mathrm{~B}=$ cytosine $(93 \%)$

$2 \mathrm{~B}=$ adenine $(89 \%)$

$10 \mathrm{~B}=2$-amino-6-chloropurine $(60 \%)$

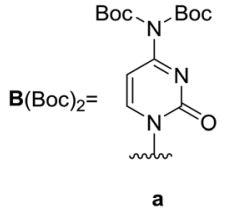

b

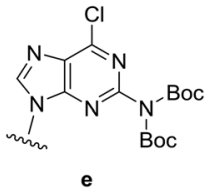

Scheme 2

actions play an important role both in the ionization and the nucleophilic attack steps. ${ }^{12}$

Having explored the feasibility of using nucleic bases as nucleophiles for the synthesis of chiral branched heterocycles via a Pd-AAA with the DACH-naphthyl Trost ligand, we selected compounds $7 \mathbf{a}, \mathbf{7 b}$ and $7 \mathbf{e}$ for synthesizing model acyclic pyrimidine and purine nucleosides.

For this purpose, the primary hydroxyl group was initially protected by reaction with tert-butyldiphenylsilyl chloride in DMF in the presence of imidazole to afford compounds $\mathbf{8 a}, \mathbf{b}, \mathbf{e}$ in excellent yields (Scheme 2). According to the retrosynthetic scheme and following previous studies in the field, ${ }^{14}$ compounds $\mathbf{8 a , b}$ were then treated with diethyl allylphosphonate $^{15,16}$ in the presence of Grubb-Nolan's catalyst to afford compounds 9a,b in excellent $92 \%$ and $90 \%$ yields, respectively, as a result of a cross-metathesis reaction. The reaction of $8 \mathrm{e}$ under similar conditions afforded $9 \mathrm{e}$ in a moderate $52 \%$ yield. Compounds with $E$ configuration were exclusively obtained. Removal of the protecting groups ${ }^{15}$ in the nucleic base, the phosphonate moiety and the hydroxyl group, was carried out by treatment of compounds $\mathbf{9 a}, \mathbf{b}$ with $\mathrm{TMSBr}^{15}$ in dichloromethane to afford the target acyclic nucleosides $\mathbf{1}$ and 2 in excellent yields. Additionally, compound 9e was treated under the deprotection conditions to afford the 2-amino-6chloro-9H-purine derivative $\mathbf{1 0}$ in good yield.

The saturated nucleoside 11, with an increased conformational mobility, was prepared by the reduction of the double bond in 9a (Scheme 3). Attempts to reduce the double bond under 1 bar of hydrogen pressure and using palladium on charcoal $^{17}$ as catalysts led to no conversion. At higher hydrogen pressure (10 bar) the presence of two products was observed by ${ }^{1} \mathrm{H}$ NMR, corresponding to the expected 
<smiles>CCOP(=O)(C/C=C\C(COC(C)(C)C)n1ccc(N(C(=O)OC(C)(C)C)C(=O)OC(C)(C)C)nc1=O)OCC</smiles>

9a
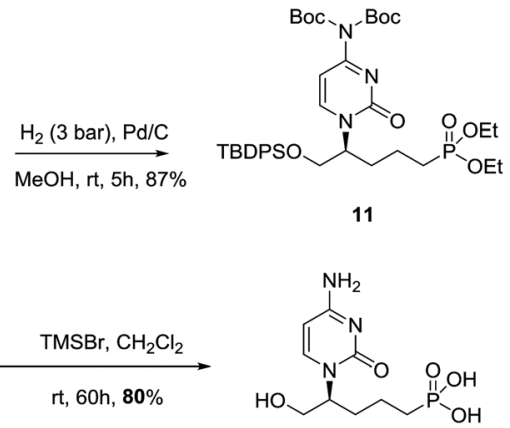

12
Scheme 3

compound $\mathbf{1 1}$ and to a secondary product resulting from the reduction of the double bond and partial reduction of the cytosine. Optimal conditions were found driving the reaction at room temperature and using 3 bar of hydrogen pressure. In this way, full conversion and $87 \%$ yield of compound $\mathbf{1 1}$ was obtained. Removal of protecting groups using TMSBr afforded acyclic nucleoside phosphonate $\mathbf{1 2}$ in $80 \%$ yield.

In conclusion, acyclic nucleosides 1, 2, 10 and 12 were successfully prepared in high yields by palladium-catalyzed allylic amination from compounds $\mathbf{4}$ and 5, using pyrimidinic and purinic bases as nucleophiles, followed by rutheniumcatalyzed cross-metathesis with diethyl allylphosphonate and removal of protecting groups. Excellent enantioselectivity was obtained for the purinic derivatives $\mathbf{2}$ and $\mathbf{1 0}$.

\section{Experimental section}

\section{General methods}

All chemicals used were reagent grade and used as supplied unless otherwise specified. HPLC grade dichloromethane $\left(\mathrm{CH}_{2} \mathrm{Cl}_{2}\right)$, tetrahydrofuran (THF) and dimethylformamide (DMF) were dried using a solvent purification system (PureSolv 400). Toluene was purified using standard procedures. ${ }^{18}$ ${ }^{1} \mathrm{H}$ and ${ }^{13} \mathrm{C}$ NMR spectra were recorded on a Varian ${ }^{\circledR}$ Mercury VX 400 (400 MHz and $100.6 \mathrm{MHz}$ respectively) or Varian 400-MR spectrometer in $\mathrm{CDCl}_{3}$ as a solvent, with chemical shifts $(\delta)$ referenced to the internal standard $\mathrm{CDCl}_{3}(7.26 \mathrm{ppm}$ ${ }^{1} \mathrm{H}, 77.23 \mathrm{ppm}{ }^{13} \mathrm{C}$ ) or $\mathrm{Me}_{4} \mathrm{Si}$ as an internal reference (0.00 ppm). 2D correlation spectra (gCOSY, NOESY, gHSQC, gHMBC) were visualized using a VNMR program (Varian®). ESI MS were run on an Agilent ${ }^{\circledR} 1100$ Series LC/MSD instrument. Optical rotations were measured at room temperature in a PerkinElmer® $241 \mathrm{MC}$ apparatus with $10 \mathrm{~cm}$ cells. IR spectra were recorded on a JASCO FT/IR-600 Plus Fourier transform infrared spectrometer ATR Specac Golden Gate. Optical rotations were measured at $598 \mathrm{~nm}$ on a Jasco DIP-370 digital polarimeter using a $100 \mathrm{~mm}$ cell. The enantiomeric excess was determined by an HPLC analysis using a DAICEL CHIRALCEL OD-H column. Reactions were monitored by TLC carried out on $0.25 \mathrm{~mm}$ E. Merck® silica gel 60 F254 glass or aluminium plates. Developed TLC plates were visualized under a shortwave UV lamp (250 $\mathrm{nm}$ ) and by heating plates that were dipped in ethanol $/ \mathrm{H}_{2} \mathrm{SO}_{4}(15: 1)$ and a basic solution of potassium permanganate. Flash column chromatography was carried out using forced flow of the indicated solvent on Fluka ${ }^{\circledR}$ or Merck® silica gel 60 (230-400 mesh). Radial chromatography was performed on 1 or $2 \mathrm{~mm}$ plates of Kieselgel 60 PF254 silica gel, depending on the amount of the product. Flash column chromatography (FCC) was performed using flash silica gel $(32-63 \mu \mathrm{m})$ and employed a solvent polarity correlated with TLC mobility.

General procedure 1. Palladium-catalyzed allylic amination from butadiene monoepoxide (4). In a Schlenk tube, $\left[\operatorname{Pd}\left(\eta^{3}\right.\right.$ $\left.\left.\mathrm{C}_{3} \mathrm{H}_{5}\right) \mathrm{Cl}\right]_{2}$ (2 mol\%), the DACH-naphthyl ligand (see tables) (6 $\mathrm{mol} \%)$, the nucleophile (2.0 eq.) and $\mathrm{CH}_{2} \mathrm{Cl}_{2}(c=0.02 \mathrm{M})$ were introduced under an argon atmosphere. The resulting solution was stirred for 20 minutes. Butadiene monoepoxide (4) (1.0 eq.) was then added in one portion. The mixture was stirred at room temperature for $18 \mathrm{~h}$. The reaction mixture was then diluted with $\mathrm{H}_{2} \mathrm{O}$. The phases were separated and the aqueous phase was extracted with $\mathrm{CH}_{2} \mathrm{Cl}_{2}$. The combined organic phases were dried over $\mathrm{MgSO}_{4}$, filtered, and concentrated under vacuum. The resulting crude was purified by flash chromatography to afford a pure product.

General procedure 2. Palladium-catalyzed allylic amination from (E)-4-hydroxybut-2-en-1-yl methyl carbonate (5). In a Schlenk tube, $\left[\mathrm{Pd}\left(\eta^{3}-\mathrm{C}_{3} \mathrm{H}_{5}\right) \mathrm{Cl}\right]_{2}(2 \mathrm{~mol} \%)$, the $(S, S)-\mathrm{DACH}-$ naphthyl ligand $(6 \mathrm{~mol} \%)$ and $\mathrm{CH}_{2} \mathrm{Cl}_{2}(c=0.02 \mathrm{M})$ were introduced under an argon atmosphere. The resulting mixture was stirred for 20 minutes. Carbonate 5 (1.0 eq.) and nucleophile (1.1 eq.) were then successively introduced. The mixture was stirred at room temperature for $18 \mathrm{~h}$. The reaction mixture was then diluted with $\mathrm{H}_{2} \mathrm{O}$. The phases were separated and the aqueous phase was extracted with $\mathrm{CH}_{2} \mathrm{Cl}_{2}$. The combined organic phases were dried over $\mathrm{MgSO}_{4}$, filtered, and concentrated under vacuum. The resulting crude was purified by flash chromatography to afford a pure product.

( $R$ )- $N, N$-Bis(tert-butoxycarbonyl)-1-(1-hydroxybut-3-en-2-yl)-cytosine (ent-7a). Following the general procedure 2, compound ent-7a was prepared from carbonate 5 (17 $\mathrm{mg}, 0.116 \mathrm{mmol})$, compound 6a (72 mg, $0.23 \mathrm{mmol}),\left[\mathrm{Pd}\left(\eta^{3}-\mathrm{C}_{3} \mathrm{H}_{5}\right) \mathrm{Cl}\right]_{2}(1 \mathrm{mg}$, $0.002 \mathrm{mmol})$ and $(S, S)$-DACH-naphthyl ligand $(5.5 \mathrm{mg}$, $0.008 \mathrm{mmol})$ in dichloromethane $(12 \mathrm{~mL})$ at $-10{ }^{\circ} \mathrm{C}$. Purification by silica chromatography (hexanes/EtOAc 10:2) provided $41 \mathrm{mg}$ (90\%) of compound $\boldsymbol{e n t}$-7a as a yellow syrup and $75 \%$ ee (determined by chiral HPLC (Daicel Chiralcel OD-H, $n$-hexane- ${ }^{\mathrm{i}} \mathrm{PrOH}, 90: 10$, flow $=0.5 \mathrm{~mL} \mathrm{~min}^{-1}$, detection, UV $210 \mathrm{~nm}$; retention times ( $\mathrm{min}), 9.79,11.42, t_{\mathrm{R}}(R)=9.79 \mathrm{~min}$ and $\left.\left.t_{\mathrm{R}}(S)=11.42 \mathrm{~min}\right)\right) \cdot[\alpha]_{\mathrm{D}}^{25}+7.13\left(c 1.06, \mathrm{CHCl}_{3}\right)$. FTIR-ATR $\left(\mathrm{cm}^{-1}\right):$ 2918, 2849, 1775, 1741, 1665, 1460, 1369, 1313, 1253, 1154, 1131, 788. ${ }^{1} \mathrm{H}$ NMR $\left(\mathrm{CDCl}_{3}, 400 \mathrm{MHz}\right.$ ): $\delta$ (ppm) 7.67 (d, $1 \mathrm{H}, J=7.5 \mathrm{~Hz}$ ), 7.05 (d, $1 \mathrm{H}, J=7.5 \mathrm{~Hz}), 6.00$ (ddd, $1 \mathrm{H}, J=17.0$, 10.6, $5.9 \mathrm{~Hz}), 5.42(\mathrm{dd}, 1 \mathrm{H}, J=10.6,1.5 \mathrm{~Hz}), 5.30(\mathrm{dd}, 1 \mathrm{H}, J=$ 17.0, $1.5 \mathrm{~Hz}$ ), 5.28-5.23 (m, 1H), 4.00-3.94 (m, 2H), 3.15 (bs, $1 \mathrm{H}), 1.55(\mathrm{~s}, 18 \mathrm{H}) \cdot{ }^{13} \mathrm{C} \mathrm{NMR}\left(\mathrm{CDCl}_{3}, 100.6 \mathrm{MHz}\right): \delta(\mathrm{ppm})$ 
161.9, 155.8, 149.7, 147.2, 147.0, 132.7, 120.5, 96.2, 85.1, 62.7, 61.2, 27.8. HRMS (ESI-TOF) $\mathrm{m} / \mathrm{z}:[\mathrm{M}+\mathrm{H}]^{+}$calcd for $\mathrm{C}_{18} \mathrm{H}_{28} \mathrm{~N}_{3} \mathrm{O}_{6}$ : 382.1973, found: 382.1964 .

(S)-N,N-Bis(tert-butoxycarbonyl)-9-(1-hydroxybut-3-en-2-yl) adenine (7b). Following the general procedure 1, compound 7b was prepared from butadiene monoepoxide (4) $(0.02 \mathrm{~mL}$, $0.25 \mathrm{mmol})$, compound $\mathbf{6 b}(100 \mathrm{mg}, 0.3 \mathrm{mmol}),\left[\mathrm{Pd}\left(\eta^{3}-\mathrm{C}_{3} \mathrm{H}_{5}\right)\right.$ $\mathrm{Cl}]_{2}$ (2 $\mathrm{mg}, 0.0054 \mathrm{mmol}$ ) and $(R, R)$-DACH-naphthyl ligand (13 $\mathrm{mg}, 0.016 \mathrm{mmol})$ in dichloromethane $(27 \mathrm{~mL})$. Purification by silica gel chromatography (hexanes/EtOAc 1:1) provided $93 \mathrm{mg}(92 \%)$ of product $7 \mathbf{b}$ as a yellow syrup and $92 \%$ ee (determined by chiral HPLC (Daicel Chiralcel OD-H, $n$-hexane- ${ }^{\mathrm{i}} \mathrm{PrOH} 85: 15$, flow $=0.5 \mathrm{~mL} \mathrm{~min}^{-1}$, detection, UV $254 \mathrm{~nm}$; retention times $(\mathrm{min}), 11.77,13.47, t_{\mathrm{R}}(R)=11.77 \mathrm{~min}$ and $\left.\left.t_{\mathrm{R}}(S)=13.47 \mathrm{~min}\right)\right) \cdot[\alpha]_{\mathrm{D}}^{25}-15.80\left(c 0.92, \mathrm{CHCl}_{3}\right)$. FTIR-ATR $\left(\mathrm{cm}^{-1}\right): 3347,2979,2926,1787,1600,1107 .{ }^{1} \mathrm{H} \mathrm{NMR}\left(\mathrm{CDCl}_{3}\right.$, $400 \mathrm{MHz}): \delta(\mathrm{ppm}) 8.84(\mathrm{~s}, 1 \mathrm{H}), 8.17(\mathrm{~s}, 1 \mathrm{H}), 6.20(\mathrm{ddd}, 1 \mathrm{H}, J=$ 17.1, 10.5, $6.4 \mathrm{~Hz}$ ), 5.40 (d, 1H, $J=10.5 \mathrm{~Hz}$ ), 5.30-5.18 (m, 1H), 5.14 (d, $1 \mathrm{H}, J=17.1 \mathrm{~Hz}$ ), 4.26-4.10 (m, 2H), 3.80 (bs, $1 \mathrm{H}), 1.47$ $(\mathrm{s}, 18 \mathrm{H}) .{ }^{13} \mathrm{C} \mathrm{NMR}\left(\mathrm{CDCl}_{3}, 100.6 \mathrm{MHz}\right): \delta(\mathrm{ppm}) 153.0,151.7$, 150.8, 150.6, 145.1, 132.7, 129.1, 119.7, 84.1, 63.8, 61.3, 27.9. HRMS (ESI-TOF) $m / z:[\mathrm{M}+\mathrm{H}]^{+}$calcd for $\mathrm{C}_{18} \mathrm{H}_{28} \mathrm{~N}_{5} \mathrm{O}_{5}$ : 406.2085, found: 406.2073 .

(R)-6-Chloro-9-(1-hydroxybut-3-en-2-yl)-9H-purine (ent-7c). Following the general procedure 1, compound ent-7c was prepared from butadiene monoepoxide (4) $(0.024 \mathrm{~mL}, 0.3 \mathrm{mmol})$, compound 6d (50 mg, $0.32 \mathrm{mmol}),\left[\mathrm{Pd}\left(\eta^{3}-\mathrm{C}_{3} \mathrm{H}_{5}\right) \mathrm{Cl}\right]_{2}(2 \mathrm{mg}$, $0.006 \mathrm{mmol})$ and $(S, S)$-DACH-naphthyl ligand (14 $\mathrm{mg}$, $0.017 \mathrm{mmol})$ in dichloromethane $(30 \mathrm{~mL})$ at rt. Purification by silica gel chromatography (hexanes/EtOAc 1:1) provided $60 \mathrm{mg}(89 \%)$ product ent-7c as a colourless oil and $91.4 \%$ ee (determined by chiral HPLC (Daicel Chiralcel OD-H, $n$-hexane- ${ }^{\mathrm{i}} \operatorname{PrOH}, 90: 10$, flow $=1 \mathrm{~mL} \mathrm{~min}^{-1}$, detection, UV $210 \mathrm{~nm}$; retention times $(\mathrm{min}), 17.12,18.36, t_{\mathrm{R}}(R)=18.36 \mathrm{~min}$ and $\left.\left.t_{\mathrm{R}}(S)=17.12 \mathrm{~min}\right)\right)$. $[\alpha]_{\mathrm{D}}^{25}+10.8\left(c\right.$ 1.23, $\left.\mathrm{CHCl}_{3}\right)$. FTIR-ATR $\left(\mathrm{cm}^{-1}\right): 3347,2927,1591,1561,1337 .{ }^{1} \mathrm{H}$ NMR $\left(\mathrm{CDCl}_{3}\right.$, $400 \mathrm{MHz}): \delta(\mathrm{ppm}) 8.70(\mathrm{~s}, 1 \mathrm{H}), 8.23(\mathrm{~s}, 1 \mathrm{H}), 6.21$ (ddd, $1 \mathrm{H}, J=$ $17.0,10.4,6.4 \mathrm{~Hz}), 5.43$ (dd, $1 \mathrm{H}, J=10.4,1.4 \mathrm{~Hz}), 5.30-5.25(\mathrm{~m}$, $1 \mathrm{H}), 5.24(\mathrm{dd}, 1 \mathrm{H}, J=17.0,1.4 \mathrm{~Hz}), 4.28-4.22(\mathrm{~m}, 1 \mathrm{H})$, 4.21-4.15 (m, 1H), $3.86(\mathrm{t}, 1 \mathrm{H}, J=6.3 \mathrm{~Hz}) .{ }^{13} \mathrm{C} \mathrm{NMR}\left(\mathrm{CDCl}_{3}\right.$, 100.6 MHz): 151.8, 151.5, 151.4, 145.4, 132.2, 131.8, 120.4, 63.7, 61.0. HRMS (ESI-TOF) $\mathrm{m} / \mathrm{z}:[\mathrm{M}+\mathrm{H}]^{+}$calcd for $\mathrm{C}_{9} \mathrm{H}_{10} \mathrm{ClN}_{4} \mathrm{O}: 225.0538$, found: 225.0532 .

(R)-1-(1-Hydroxybut-3-en-2-yl)-1H-benzo[d]imidazole (ent-7d). Following the general procedure 2, compound ent-7d was prepared from carbonate 5 (17 $\mathrm{mg}, 0.116 \mathrm{mmol})$, compound $6 \mathbf{d}$ (72 mg, $0.23 \mathrm{mmol}),\left(\eta^{3} \mathrm{C}_{3} \mathrm{H}_{5} \mathrm{PdCl}\right)_{2}(1 \mathrm{mg}, 0.002 \mathrm{mmol})$ and $(S, S)$-DACH-naphthyl ligand $(5.5 \mathrm{mg}, 0.008 \mathrm{mmol})$ in dichloromethane $(12 \mathrm{~mL})$. Purification by silica gel chromatography (hexanes/EtOAc 1:1) provided $20 \mathrm{mg}$ (92\%) of product ent-7d as a colourless oil and $88 \%$ ee (determined by chiral HPLC (Daicel Chiralcel OD-H, $n$-hexane- ${ }^{\mathrm{i}} \mathrm{PrOH}, 92: 08$, flow $=1.0 \mathrm{~mL}$ $\min ^{-1}$, detection, UV $220 \mathrm{~nm}$; retention times (min), 17.84, $25.57, t_{\mathrm{R}}(R)=17.84 \mathrm{~min}$ and $\left.\left.t_{\mathrm{R}}(S)=25.57 \mathrm{~min}\right)\right) \cdot[\alpha]_{\mathrm{D}}^{25}+26.0$ (c $\left.0.80, \mathrm{CHCl}_{3}\right)$. FTIR-ATR $\left(\mathrm{cm}^{-1}\right):$ 3089, 2922, $1492,1457$. ${ }^{1} \mathrm{H} \mathrm{NMR}\left(\mathrm{CDCl}_{3}, 400 \mathrm{MHz}\right): \delta(\mathrm{ppm}) 7.84(\mathrm{~s}, 1 \mathrm{H}), 7.53(\mathrm{~d}, 1 \mathrm{H}$,
$J=7.7 \mathrm{~Hz}), 7.36(\mathrm{~d}, 1 \mathrm{H}, J=7.7 \mathrm{~Hz}), 7.21(\mathrm{t}, 1 \mathrm{H}, J=7.7 \mathrm{~Hz}), 7.14$ $(\mathrm{t}, 1 \mathrm{H}, J=7.7 \mathrm{~Hz}), 6.11(\mathrm{ddd}, 1 \mathrm{H}, J=17.0,10.8,5.7 \mathrm{~Hz}), 5.37$ (d, $1 \mathrm{H}, J=10.8 \mathrm{~Hz}), 5.20$ (d, $1 \mathrm{H}, J=17.0 \mathrm{~Hz}), 5.05-4.97(\mathrm{~m}, 1 \mathrm{H})$, 4.22-4.10 (m, 2H). ${ }^{13} \mathrm{C} \mathrm{NMR}\left(\mathrm{CDCl}_{3}, 100.6 \mathrm{MHz}\right): \delta(\mathrm{ppm})$ 143.2, 142.2, 140.8, 132.9, 123.0, 122.5, 119.8, 119.4, 110.7, 63.3, 60.6. HRMS (ESI-TOF) $m / z:[\mathrm{M}+\mathrm{H}]^{+}$calcd for $\mathrm{C}_{11} \mathrm{H}_{13} \mathrm{~N}_{2} \mathrm{O}$ : 189.1022, found: 189.1017.

(S)-2-Bis-tert-butoxycarbonyl-amino-6-chloro-9-(1-hydroxybut3-en-2-yl)-9H-purine (7e). Following the general procedure 2, compound 7e was prepared from carbonate 5 (17 mg, $0.116 \mathrm{mmol})$, compound $6 \mathrm{e}(85 \mathrm{mg}, 0.23 \mathrm{mmol}),\left[\mathrm{Pd}\left(\eta^{3}-\mathrm{C}_{3} \mathrm{H}_{5}\right)\right.$ $\mathrm{Cl}]_{2}(1 \mathrm{mg}, 0.002 \mathrm{mmol})$ and $(R, R)$-DACH-naphthyl ligand (5.5 mg, $0.008 \mathrm{mmol})$ in dichloromethane $(6 \mathrm{~mL})$ at room temperature. Purification by silica chromatography (hexanes/ EtOAc $4: 6)$ provided $22 \mathrm{mg}(43 \%)$ of compound $7 \mathrm{e}$ as a yellow syrup and $92 \%$ ee (determined by chiral HPLC (Daicel Chiralcel OD-H, $n$-hexane- ${ }^{\mathrm{i}} \mathrm{PrOH}, 90: 10$, flow $=0.6 \mathrm{~mL} \mathrm{~min}{ }^{-1}$, detection, UV $230 \mathrm{~nm}$; retention times $(\min ), 13.5,15.1, t_{\mathrm{R}}(R)=$ $13.5 \mathrm{~min}$ and $\left.t_{\mathrm{R}}(S)=15.1 \mathrm{~min}\right)$ ). $[\alpha]_{\mathrm{D}}^{25}-34.0\left(c \quad 0.1, \mathrm{CHCl}_{3}\right)$. ${ }^{1} \mathrm{H} \mathrm{NMR}\left(\mathrm{CDCl}_{3}, 400 \mathrm{MHz}\right): \delta(\mathrm{ppm}) 8.25(\mathrm{~s}, 1 \mathrm{H}), 6.17$ (ddd, $J=$ $16.9,10.5,6.3 \mathrm{~Hz}, 1 \mathrm{H}), 5.40$ (d, $J=10.4 \mathrm{~Hz}, 1 \mathrm{H}), 5.24-5.16(\mathrm{~m}$, $2 \mathrm{H}), 4.22(\mathrm{dd}, J=12,5.9 \mathrm{~Hz}, 1 \mathrm{H}), 4.11(\mathrm{dd}, J=12.0,3.0 \mathrm{~Hz}, 1 \mathrm{H})$, 3.27 (br s, 1H), 1.44 (s, 18H). ${ }^{13} \mathrm{C} \mathrm{NMR}\left(\mathrm{CDCl}_{3}, 100.6 \mathrm{MHz}\right.$,): $\delta$ (ppm) 152.2, 151.5, 151.3, 150.4, 146.0, 132.2, 129.9, 120.0, 83.9, 63.4, 60.9, 27.8. HRMS (ESI-TOF) $\mathrm{m} / \mathrm{z}:[\mathrm{M}+\mathrm{Na}]^{+}$calcd for $\mathrm{C}_{19} \mathrm{H}_{26} \mathrm{ClN}_{5} \mathrm{O}_{5} \mathrm{Na}: 462.1520$, found: 462.1524 .

(S)-N,N-Bis(tert-butoxycarbonyl)-1-[1-(tert-butyldiphenyl-silyloxy) but-3-en-2-yl]cytosine (8a). Compound 7a (100 mg, $0.26 \mathrm{mmol}$ ) was dissolved in dry DMF (3 mL), treated under argon with tert-butyldiphenylchlorosilane $(0.08 \mathrm{~mL}, 0.3 \mathrm{mmol})$ and imidazole ( $40 \mathrm{mg}, 0.6 \mathrm{mmol}$ ), and the reaction mixture was stirred for $16 \mathrm{~h}$ at room temperature. The solution was then diluted with water and extracted with $\mathrm{Et}_{2} \mathrm{O}$, and the organic layer was dried and evaporated. The residue was purified by column chromatography on silica gel (hexanes/EtOAc $10: 2$ ) to provide $137 \mathrm{mg}(85 \%)$ of compound 8a. $[\alpha]_{\mathrm{D}}^{25}-13.5$ (c 1.27, $\mathrm{CHCl}_{3}$ ). FTIR-ATR $\left(\mathrm{cm}^{-1}\right): 2931,2857,1742,1671,1524,1455,1370$, 1319, 1256, 1137, 1110, 784, 701. ${ }^{1} \mathrm{H} \mathrm{NMR}\left(\mathrm{CDCl}_{3}, 400 \mathrm{MHz}\right)$ : $\delta(\mathrm{ppm}) 7.75(\mathrm{~d}, 1 \mathrm{H}, J=7.5 \mathrm{~Hz}), 7.57(\mathrm{~d}, 2 \mathrm{H}, J=6.4 \mathrm{~Hz}), 7.48$ (d, 2H, $J=6.4 \mathrm{~Hz}), 7.49-7.30(\mathrm{~m}, 6 \mathrm{H}), 7.98(\mathrm{~d}, 1 \mathrm{H}, J=7.5 \mathrm{~Hz})$, 6.01 (ddd, 1H, $J=17.6,10.4,6.0 \mathrm{~Hz}$ ), 5.38-5.34 (m, 2H), 5.32 (d, $1 \mathrm{H}, J=17.6 \mathrm{~Hz}$ ), 3.97 (d, 2H, $J=3.6 \mathrm{~Hz}), 1.57$ (s, 18H), 1.02 (s, 9H). ${ }^{13} \mathrm{C} \mathrm{NMR}\left(\mathrm{CDCl}_{3}, 100.6 \mathrm{MHz}\right): \delta$ (ppm) 161.9, 155.0, 149.8, 147.1, 135.7, 135.5, 133, 132.6, 130.1, 128.0, 120.6, 95.6, 84.9, 63.9, 59.6, 27.9, 26.7, 19.3. HRMS (ESI-TOF) $m / z:[\mathrm{M}+\mathrm{H}]^{+}$ calcd for $\mathrm{C}_{34} \mathrm{H}_{46} \mathrm{~N}_{3} \mathrm{O}_{6} \mathrm{Si} 620.3156$, found 620.3171.

(S)-N,N-Bis(tert-butoxycarbonyl)-9-[1-(tert-butyldiphenylsilyloxy) but-3-en-2-yl] adenine (8b). Compound 7 b (250 mg, $0.6 \mathrm{mmol}$ ) was dissolved in dry DMF $(7 \mathrm{~mL})$ and treated under argon with tert-butyldiphenylchlorosilane $(0.18 \mathrm{~mL}, 0.66 \mathrm{mmol})$ and imidazole ( $90 \mathrm{mg}, 1.32 \mathrm{mmol}$ ), and the mixture was then stirred for $16 \mathrm{~h}$ at room temperature. The solution was then diluted with water and extracted with $\mathrm{Et}_{2} \mathrm{O}$, and the organic layer was dried and evaporated. The residue was purified by column chromatography on silica gel (hexanes/EtOAc $10: 2$ ) to provide $319 \mathrm{mg}(80 \%)$ of compound $\mathbf{8 b}$ as a colourless oil. $[\alpha]_{\mathrm{D}}^{25}$ 
-10.93 (c 1.13, $\left.\mathrm{CHCl}_{3}\right)$. FTIR-ATR $\left(\mathrm{cm}^{-1}\right): 2987,2362,1733$, 1716, 1558, 1540, 1507, 1456, 1395, 1259, 1066, 749. ${ }^{1} \mathrm{H}$ NMR $\left(\mathrm{CDCl}_{3}, 400 \mathrm{MHz}\right): \delta(\mathrm{ppm}) 8.79(\mathrm{~s}, 1 \mathrm{H}), 8.26(\mathrm{~s}, 1 \mathrm{H}), 7.50-7.25$ $(\mathrm{m}, 10 \mathrm{H}), 6.02$ (ddd, $1 \mathrm{H}, J=17.2,10.4,6.4 \mathrm{~Hz}), 5.34(\mathrm{dd}, 1 \mathrm{H}$, $J=11.6,0.8 \mathrm{~Hz}), 5.30-5.20(\mathrm{~m}, 1 \mathrm{H}), 5.17(\mathrm{dd}, 1 \mathrm{H}, J=17.2,0.8$ $\mathrm{Hz}$ ), $4.16(\mathrm{dd}, 1 \mathrm{H}, J=11.2,6.8 \mathrm{~Hz}), 4.05(\mathrm{dd}, 1 \mathrm{H}, J=10.8,4$ $\mathrm{Hz}), 1.43$ (s, 18H), 0.94 (s, 9H). ${ }^{13} \mathrm{C} \mathrm{NMR}\left(\mathrm{CDCl}_{3}, 100.6 \mathrm{MHz}\right)$ : $\delta(\mathrm{ppm}) 153.3,151.8,150.5,150.3,144.5,135.5,135.4,132.5$, 130.1, 128.9, 127.9, 119.8, 83.7, 64.8, 59.4, 27.9, 26.8, 19.1. HRMS (ESI-TOF) $m / z$ : $[\mathrm{M}+\mathrm{Na}]^{+}$calcd for $\mathrm{C}_{35} \mathrm{H}_{45} \mathrm{~N}_{5} \mathrm{NaO}_{5} \mathrm{Si}$ 666.3088 , found 666.3073 .

(S)-2-Bis-tert-butoxycarbonyl-amino-6-chloro-9-[1-(tert-butyl diphenylsilyloxy)-but-3-en-2-yl]-9H-purine (8e). Compound 7e (113 mg, $0.257 \mathrm{mmol}$ ) was dissolved in dry DMF (3 mL) and treated under argon with tert-butyldiphenylchlorosilane $(80.1 \mu \mathrm{L}, 0.308 \mathrm{mmol})$ and imidazole $(40 \mathrm{mg}, 0.59 \mathrm{mmol})$, and the mixture was then stirred for $16 \mathrm{~h}$ at room temperature. The solution was then diluted with water and extracted with $\mathrm{Et}_{2} \mathrm{O}$, and the organic layer was dried and evaporated. The residue was purified by column chromatography on silica gel (hexanes/EtOAc $10: 2$ ) to provide $244 \mathrm{mg}$ (95\%) of compound 8e as a colourless oil. $[\alpha]_{\mathrm{D}}^{25}-11.0\left(c \quad 0.3, \mathrm{CHCl}_{3}\right) .{ }^{1} \mathrm{H} \mathrm{NMR}$ $\left(400 \mathrm{MHz}, \mathrm{CDCl}_{3}\right) \delta 8.33(\mathrm{~s}, 1 \mathrm{H}), 7.55-7.51(\mathrm{~m}, 2 \mathrm{H}), 7.49-7.46$ $(\mathrm{m}, 2 \mathrm{H}), 7.45-7.30(\mathrm{~m}, 6 \mathrm{H}), 6.16$ (ddd, $J=17.0,10.5,6.3 \mathrm{~Hz}$, $1 \mathrm{H}), 5.34(\mathrm{dd}, J=10.5,0.8 \mathrm{~Hz}, 1 \mathrm{H}), 5.27-5.19(\mathrm{~m}, 1 \mathrm{H})$, $5.18-5.09(\mathrm{~m}, 1 \mathrm{H}), 4.13(\mathrm{dd}, J=11.1,5.6 \mathrm{~Hz}, 1 \mathrm{H}), 4.01(\mathrm{dd}, J=$ 11.1, 3.8 Hz, 1H), 1.39 (s, 18H), 1.01-0.95 (m, 9H). ${ }^{13} \mathrm{C}$ NMR $\left(100 \mathrm{MHz}, \mathrm{CDCl}_{3}\right) \delta 152.4,151.7,150.9,150.4,145.7,135.5$, 135.3, 132.3, 132.2, 132.1, 130.1, 130.0, 129.7, 127.9, 119.9, 83.4, 64.7, 59.2, 27.8, 26.7, 19.1. HRMS (ESI-TOF) $\mathrm{m} / \mathrm{z}:[\mathrm{M}+\mathrm{Na}]^{+}$calcd for $\mathrm{C}_{35} \mathrm{H}_{44} \mathrm{ClN}_{5} \mathrm{O}_{5} \mathrm{SiNa}$ : 700.2698, found: 700.2700.

Diethyl $(2 E, 4 S)-N, N$-bis(tert-butoxycarbonyl)-1-[1-(tert-butyldiphenylsilyloxy)-5-phosphonopent-3-en-2-yl]cytosine (9a). To a solution of product $\mathbf{8 a}(50 \mathrm{mg}, 0.08 \mathrm{mmol})$ and II generation Grubbs catalyst (4 mg, $0.004 \mathrm{mmol}$ ) in dichloromethane (4 $\mathrm{mL})$ was added diethylallylphosphonate $(0.06 \mathrm{~mL}$, $0.32 \mathrm{mmol}$ ) and the reaction mixture was heated to reflux for $16 \mathrm{~h}$. The solvent was then evaporated and the reaction crude was purified by silica gel chromatography (hexanes/EtOAc $1: 2$ ) to provide $57 \mathrm{mg}$ (92\%) of compound 9a as a yellow liquid. $[\alpha]_{\mathrm{D}}^{25}-21.4$ (c 1.2, $\left.\mathrm{CHCl}_{3}\right)$. FTIR-ATR $\left(\mathrm{cm}^{-1}\right):$ 2969, 2931, 1741, 1671, 1455, 1370, 1319, 1255, 1111, 1024, 735, 701. ${ }^{1} \mathrm{H}$ NMR $\left(\mathrm{CDCl}_{3}, 400 \mathrm{MHz}\right): \delta(\mathrm{ppm}) 7.68(\mathrm{~d}, 1 \mathrm{H}, J=7.6 \mathrm{~Hz}), 7.56(\mathrm{~d}, 2 \mathrm{H}$, $J=6.4 \mathrm{~Hz}), 7.45$ (d, 2H, $J=6.4 \mathrm{~Hz}), 7.42-7.30(\mathrm{~m}, 6 \mathrm{H}), 6.97$ (d, $1 \mathrm{H}, J=7.6 \mathrm{~Hz}), 5.87-5.79(\mathrm{~m}, 2 \mathrm{H}), 5.29$ (brs, $1 \mathrm{H}), 4.15-4.02(\mathrm{~m}$, $4 \mathrm{H}), 3.96(\mathrm{~d}, 2 \mathrm{H}, J=4.0 \mathrm{~Hz}), 2.60(\mathrm{dd}, 2 \mathrm{H}, J=21.0,6.4 \mathrm{~Hz})$, $1.57(\mathrm{~s}, 18 \mathrm{H}), 1.27$ (t, 6H, $J=6.8 \mathrm{~Hz}), 1.03(\mathrm{~s}, 9 \mathrm{H}) .{ }^{13} \mathrm{C}$ NMR $\left(\mathrm{CDCl}_{3}, 100.6 \mathrm{MHz}\right): \delta$ (ppm) 161.7, 154.6, 149.5, 146.9, 135.5, $135.3,132.5,132.4,130,129.9,129.5,129.4,128.5,127.8$, 126.5, 126.3, 95.4, 84.7, 63.6, 62, 59.4, $30.6(J=140 \mathrm{~Hz}) 27.7$, 26.8, 19.1, 16.4. HRMS (ESI-TOF) $m / z:[\mathrm{M}+\mathrm{H}]^{+}$calcd for $\mathrm{C}_{39} \mathrm{H}_{57} \mathrm{~N}_{3} \mathrm{O}_{9} \mathrm{PSi} 770.3602$, found 770.3628 .

Diethyl (2E,4S)-N,N-bis(tert-butoxycarbonyl)-1-[1-(tert-butyldiphenylsilyloxy)-5-phosphonopent-3-en-2-yl] adenine (9b). To a solution of product $\mathbf{8 b}(140 \mathrm{mg}, 0.22 \mathrm{mmol})$ and II generation Grubbs catalyst ( $9 \mathrm{mg}, 0.011 \mathrm{mmol}$ ) in dichloromethane
$(11 \mathrm{~mL})$ was added diethylallylphosphonate $(0.16 \mathrm{~mL}$, $0.88 \mathrm{mmol}$ ) and the reaction mixture was heated to reflux for $16 \mathrm{~h}$. The solvent was then evaporated and the reaction crude was purified by silica gel chromatography (hexanes/EtOAc $2: 1$ ) to provide $157 \mathrm{mg}(90 \%)$ of product $\mathbf{9 b}$ as a green liquid. $[\alpha]_{\mathrm{D}}^{25}$ -14.6 (c 1.36, $\mathrm{CHCl}_{3}$ ). FTIR-ATR $\left(\mathrm{cm}^{-1}\right)$ : 2929, 2856, 1788, 1599, 1452, 1369, 1252, 1139, 1111, 1026, 704. ${ }^{1} \mathrm{H}$ NMR $\left(\mathrm{CDCl}_{3}, 400 \mathrm{MHz}\right): \delta(\mathrm{ppm}) 8.77(\mathrm{~s}, 1 \mathrm{H}), 8.20(\mathrm{~s}, 1 \mathrm{H}), 7.42-7.29$ (m, 10H), 6.15-6.02 (m, 1H), 5.76 (ddd, 1H, $J=15.6,10.4,7.6$ $\mathrm{Hz}$ ), 5.25 (brs, 1H), 4.16 (dd, $2 \mathrm{H}, J=10.4,6.4 \mathrm{~Hz}$ ), 4.07-3.95 $(\mathrm{m}, 4 \mathrm{H}), 2.56(\mathrm{dd}, 1 \mathrm{H}, J=21.0,7.6 \mathrm{~Hz}), 1.43(\mathrm{~s}, 18 \mathrm{H}), 1.22(\mathrm{t}$, $6 \mathrm{H}, J=6.8 \mathrm{~Hz}), 0.93(\mathrm{~s}, 9 \mathrm{H}) .{ }^{13} \mathrm{C} \mathrm{NMR}\left(\mathrm{CDCl}_{3}, 100.6 \mathrm{MHz}\right): \delta$ (ppm) 153.2, 151.9, 150.6, 150.4, 144.5, 135.2, 132.4, 130.1, $129.1,129.0,128.0,126.2,83.8,64.8,62.2,62.1,59.2,30.6(J=$ $140 \mathrm{~Hz}$ ), 28.0, 26.9, 19.2, 16.6. HRMS (ESI-TOF) $m / z:[\mathrm{M}+\mathrm{H}]^{+}$ calcd for $\mathrm{C}_{40} \mathrm{H}_{57} \mathrm{~N}_{5} \mathrm{O}_{8} \mathrm{PSi} 794.3714$, found 794.3694 .

Diethyl $(2 E, 4 S)$ 2-bis-tert-butoxycarbonyl-amino-6-chloro-9[1-(tert-butyl-diphenylsilyloxy)-5-phosphonopent-3-en-2-yl]-9Hpurine (9e). To a solution of product $8 \mathrm{e}(134 \mathrm{mg}, 0.197 \mathrm{mmol})$ and II generation Grubbs catalyst ( $8 \mathrm{mg}, 0.009 \mathrm{mmol}$ ) in dichloromethane $(8 \mathrm{~mL})$ was added diethylallylphosphonate $(0.134 \mathrm{~mL}, 0.788 \mathrm{mmol})$ and the reaction mixture was heated to reflux for $16 \mathrm{~h}$. The solvent was then evaporated and the reaction crude was purified by silica gel chromatography (hexanes/EtOAc 1:2) to provide $86 \mathrm{mg}$ (52\%) of compound 9e as a colourless oil. $[\alpha]_{\mathrm{D}}^{25}-2.4\left(c 0.4, \mathrm{CHCl}_{3}\right) .{ }^{1} \mathrm{H}$ NMR $(400 \mathrm{MHz}$, $\left.\mathrm{CDCl}_{3}\right) \delta 8.22(\mathrm{~s}, 1 \mathrm{H}), 7.55-7.26(\mathrm{~m}, 10 \mathrm{H}), 6.09-5.98(\mathrm{~m}, 1 \mathrm{H})$, $5.75(\mathrm{dt}, J=14.6,7.0 \mathrm{~Hz}, 1 \mathrm{H}), 5.18$ (brs, $1 \mathrm{H}), 4.10$ (dd, $J=11.0$, $5.6 \mathrm{~Hz}, 2 \mathrm{H}$ ), 4.03 (ddd, $J=14.3,9.3,5.3 \mathrm{~Hz}, 2 \mathrm{H}), 3.96$ (dd, $J=$ 11.0, $3.8 \mathrm{~Hz}, 2 \mathrm{H}), 2.61$ (d, $J=7.4 \mathrm{~Hz}, 1 \mathrm{H}), 2.55$ (d, $J=7.4 \mathrm{~Hz}$, $1 \mathrm{H}), 1.40$ (s, 18H), 1.24 (dd, $J=12.8,7.0 \mathrm{~Hz}, 6 \mathrm{H}), 0.97$ (s, 9H). ${ }^{13} \mathrm{C} \mathrm{NMR}\left(100 \mathrm{MHz}, \mathrm{CDCl}_{3}\right) \delta 152.1,151.6,150.9,150.5,145.5$, $135.4,135.3,132.1,130.1,130.0,129.8,128.6,128.5,127.9$, $127.8,126.5,126.4,83.5,64.7,62.1,61.9,58.7,31.2,29.8,27.9$, $26.7,19.0,16.5,16.4,16.3$. HRMS (ESI-TOF) $m / z:[\mathrm{M}+\mathrm{H}]^{+}$calcd for $\mathrm{C}_{40} \mathrm{H}_{56} \mathrm{ClN}_{5} \mathrm{O}_{8} \mathrm{PSi}$ : 828.3324, found 828.3364.

(2E,4S)-1-[5-Phosphono-1-hydroxypent-3-en-2-yl]cytosine (1). TMSBr $(0.08 \mathrm{~mL}, 0.6 \mathrm{mmol})$ was added to a solution of compound 9a (80 mg, $0.10 \mathrm{mmol})$ in $\mathrm{CH}_{2} \mathrm{Cl}_{2}(7 \mathrm{~mL})$, and the mixture was stirred for $60 \mathrm{~h}$ at room temperature under positive pressure of dry Ar. The reaction was quenched by adding $\mathrm{MeOH}(3 \mathrm{~mL})$ and the reaction mixture was then evaporated by heating at $60{ }^{\circ} \mathrm{C}$. This process was repeated three times. The resulting residue was extracted with $\mathrm{H}_{2} \mathrm{O}$ and $\mathrm{CH}_{2} \mathrm{Cl}_{2}$, and the aqueous phase was evaporated to dryness to afford compound 1 (25 mg, 93\%) as a yellow liquid. $[\alpha]_{\mathrm{D}}^{25}-11.2(c 2.89, \mathrm{MeOH})$. FTIR-ATR (cm $\left.{ }^{-1}\right): 2969,1715,1669,1540,1394,1043,973,872$, 793, 762, 748, 702. ${ }^{1} \mathrm{H}$ NMR $\left(\mathrm{D}_{2} \mathrm{O}, 400 \mathrm{MHz}\right): \delta(\mathrm{ppm}) 7.85(\mathrm{~d}$, $1 \mathrm{H}, J=7.8 \mathrm{~Hz}), 6.16(\mathrm{~d}, 1 \mathrm{H}, J=7.8 \mathrm{~Hz}), 5.75-5.56(\mathrm{~m}, 2 \mathrm{H}), 5.16$ (bs, $1 \mathrm{H}), 3.88$ (d, 2H, $J=6.0 \mathrm{~Hz}$ ), 2.45 (d, 2H, $J=21.0,7.0 \mathrm{~Hz}$ ). ${ }^{13} \mathrm{C}$ NMR (D $\left.{ }_{2} \mathrm{O}, 100.6 \mathrm{MHz}\right): \delta(\mathrm{ppm}) 158.8,149.0,147.0,127.5$, 127.4, 94.6, 60.9, 59.8, 31.8 (d, $J=130 \mathrm{~Hz}$ ). HRMS (ESI-TOF) $m / z:[\mathrm{M}+\mathrm{H}]^{+}$calcd for $\mathrm{C}_{9} \mathrm{H}_{14} \mathrm{~N}_{3} \mathrm{O}_{5} \mathrm{P} 276.0749$, found 276.0719.

(2E,4S)-1-[5-Phosphono-1-hydroxypent-3-en-2-yl]adenine (2). TMSBr $(0.64 \mathrm{~mL}, 0.36 \mathrm{mmol})$ was added to a solution of compound 9b (50 mg, $0.06 \mathrm{mmol}$ ) in $\mathrm{CH}_{2} \mathrm{Cl}_{2}(4 \mathrm{~mL})$, and the 
mixture was stirred for $60 \mathrm{~h}$ at room temperature under positive pressure of dry Ar. The reaction was quenched by adding $\mathrm{MeOH}(3 \mathrm{~mL})$ and the reaction mixture was then evaporated by heating at $60{ }^{\circ} \mathrm{C}$. This process was repeated three times. The resulting residue was extracted with $\mathrm{H}_{2} \mathrm{O}$ and $\mathrm{CH}_{2} \mathrm{Cl}_{2}$, and the aqueous phase was evaporated to dryness to afford compound $2(16 \mathrm{mg}, 89 \%)$ as a yellow liquid. $[\alpha]_{\mathrm{D}}^{25}-12.4(c 1.93, \mathrm{MeOH})$. FTIR-ATR $\left(\mathrm{cm}^{-1}\right): 3070,2325,1691,1609,1531,1496,1425$, 1387, 1224, 1107, 937, 770. ${ }^{1} \mathrm{H}$ NMR ( $\left.\mathrm{D}_{2} \mathrm{O}, 400 \mathrm{MHz}\right): \delta(\mathrm{ppm})$ $8.44(\mathrm{~s}, 1 \mathrm{H}), 8.40(\mathrm{~d}, 1 \mathrm{H}), 6.07-5.97(\mathrm{~m}, 1 \mathrm{H}), 5.84-5.69(\mathrm{~m}, 1 \mathrm{H})$, $5.38-5.31(\mathrm{~m}, 1 \mathrm{H}), 4.12(\mathrm{dd}, 1 \mathrm{H}, J=12.0,8.4 \mathrm{~Hz}), 4.06(\mathrm{dd}, 1 \mathrm{H}$, $J=12.0,5.2 \mathrm{~Hz}), 2.62(\mathrm{dd}, 2 \mathrm{H}, J=21.0,7.0 \mathrm{~Hz}) .{ }^{13} \mathrm{C} \mathrm{NMR}\left(\mathrm{D}_{2} \mathrm{O}\right.$, 100.6 MHz): $\delta$ (ppm) 149.6, 148.3, 143.9, 143.6, 127.8, 127.6, 118.1, 62.3, 59.2, 32.4 (d, $J=130 \mathrm{~Hz}$ ). HRMS (ESI-TOF) $\mathrm{m} / \mathrm{z}$ : $[\mathrm{M}+\mathrm{Na}]^{+}$calcd for $\mathrm{C}_{10} \mathrm{H}_{15} \mathrm{~N}_{5} \mathrm{NaO}_{4} \mathrm{P} 323.0759$, found 323.0769.

(2E,4S)-2-Amino-6-chloro-9-(5-phosphono-1-hydroxypent-3-en2-yl)-9H-purine (10). TMSBr $(0.75 \mathrm{~mL}, 0.572 \mathrm{mmol})$ was added to a solution of compound $9 \mathrm{e}(79 \mathrm{mg}, 0.095 \mathrm{mmol})$ in $\mathrm{CH}_{2} \mathrm{Cl}_{2}$ $(7 \mathrm{~mL})$, and the mixture was stirred for $60 \mathrm{~h}$ at room temperature under positive pressure of dry Ar. The reaction was quenched by adding $\mathrm{MeOH}(3 \mathrm{~mL})$ and the reaction mixture was then evaporated by heating at $60{ }^{\circ} \mathrm{C}$. This process was repeated three times. The resulting residue was extracted with $\mathrm{H}_{2} \mathrm{O}$ and $\mathrm{CH}_{2} \mathrm{Cl}_{2}$, and the aqueous phase was evaporated to dryness to afford compound $10(19 \mathrm{mg}, 60 \%)$ as a brown oil. $[\alpha]_{\mathrm{D}}^{25}+6.22(c 0.9, \mathrm{MeOH}) .{ }^{1} \mathrm{H}$ NMR $\left(500 \mathrm{MHz}, \mathrm{D}_{2} \mathrm{O}\right) \delta 8.92(\mathrm{~s}$, $1 \mathrm{H}), 5.98-5.88(\mathrm{~m}, 1 \mathrm{H}), 5.79(\mathrm{td}, J=14.4,7.0 \mathrm{~Hz}, 1 \mathrm{H}), 5.23(\mathrm{br}$ s, $1 \mathrm{H}), 4.03(\mathrm{dd}, J=12.2,6.5 \mathrm{~Hz}, 1 \mathrm{H}), 3.97(\mathrm{dd}, J=12.2,4.1 \mathrm{~Hz}$, $1 \mathrm{H}), 2.64$ (d, $J=7.3 \mathrm{~Hz}, 1 \mathrm{H}), 2.59$ (d, $J=7.4 \mathrm{~Hz}, 1 \mathrm{H}) .{ }^{13} \mathrm{C} \mathrm{NMR}$ $\left(126 \mathrm{MHz}, \mathrm{D}_{2} \mathrm{O}\right) \delta 155.2,149.9,137.5,136.7,135.6,128.0$, 107.7, 61.8, 60.9 (m), 31.2 (d, $J=132.1 \mathrm{~Hz}$ ). HRMS (ESI-TOF) $m / z:[\mathrm{M}+\mathrm{Na}]^{+}$calcd for $\mathrm{C}_{10} \mathrm{H}_{13} \mathrm{ClN}_{5} \mathrm{NaO}_{4} \mathrm{P}$ 356.0291, found 356.0381 .

Diethyl ( $S$ )- $N, N$-bis(tert-butoxycarbonyl)-1-[1-(tert-butyldiphenylsilyloxy)-5-phosphonopent-2-yl]cytosine (11). To a solution of 9a (150 mg, $0.2 \mathrm{mmol}$ ) in $\mathrm{MeOH}(6 \mathrm{~mL}), 5 \%$ palladium/carbon was added. The mixture was stirred under a hydrogen pressure ( 3 bar) at room temperature for $5 \mathrm{~h}$. The reaction mixture was then filtered through Celite, washed with $\mathrm{MeOH}$ and concentrated under reduced pressure. The crude was purified by silica gel column chromatography (EtOAc) to give the compound 11 as a colourless oil $(0.134 \mathrm{~g}, 87 \%)$. $[\alpha]_{\mathrm{D}}^{25}-16.0$ (c 2.00, $\mathrm{CHCl}_{3}$ ). FTIR-ATR (neat) 2930, 1743, 1669, 1456, 1320, 1264, 1137, 1113, 733, $702 \mathrm{~cm}^{-1} \cdot{ }^{1} \mathrm{H} \mathrm{NMR}\left(\mathrm{CDCl}_{3}, 400 \mathrm{MHz}\right)$ : $\delta(\mathrm{ppm}) 7.72(\mathrm{~d}, 1 \mathrm{H}, J=7.2 \mathrm{~Hz}), 7.55(\mathrm{~d}, 2 \mathrm{H}, J=7.6 \mathrm{~Hz}), 7.47$ $(\mathrm{d}, 2 \mathrm{H}, J=7.6 \mathrm{~Hz}), 7.40-7.30(\mathrm{~m}, 6 \mathrm{H}), 6.99(\mathrm{~d}, 1 \mathrm{H}, J=7.2 \mathrm{~Hz})$, 4.80 (brs, 1H), 4.12-3.93 (m, 4H), 3.84 (dd, $1 \mathrm{H}, J=3.6,11.2$ $\mathrm{Hz}), 3.80(\mathrm{dd}, 1 \mathrm{H}, J=3.2,11.2 \mathrm{~Hz}), 1.95-1.86(\mathrm{~m}, 2 \mathrm{H})$, 1.77-1.63 (m, 4H), 1.55 (s, 18H), $1.26(\mathrm{t}, 6 \mathrm{H}, J=6.8 \mathrm{~Hz}), 1.01(\mathrm{~s}$, 9H). ${ }^{13} \mathrm{C} \mathrm{NMR}\left(\mathrm{CDCl}_{3}, 100.6 \mathrm{MHz}\right): \delta$ (ppm) 161.8, 155.3, $149.8,146.2$, 135.7, 132.7, 130.2, 128.0, 95.7, 85, 64.4, 61.8, 61.7, 29.8, 27.9, $26.5(J=140 \mathrm{~Hz}), 24.5,19.3$, 16.7, 16.6. HRMS (ESI-TOF) $m / z:[\mathrm{M}+\mathrm{H}]^{+}$calcd for $\mathrm{C}_{39} \mathrm{H}_{59} \mathrm{~N}_{3} \mathrm{O}_{9} \mathrm{PSi} 772.3758$, found: 772.3733 .

(S)-1-[5-Phosphono-1-hydroxypent-2-yl]cytosine (12). TMSBr $(0.15 \mathrm{ml}, 0.9 \mathrm{mmol})$ was added to a solution of compound $\mathbf{1 1}$
(120 mg, $0.15 \mathrm{mmol}$ ) in $\mathrm{CH}_{2} \mathrm{Cl}_{2}(12 \mathrm{~mL})$ and the mixture was stirred for $60 \mathrm{~h}$ at room temperature under positive argon pressure. Then $\mathrm{MeOH}(3 \mathrm{~mL}$ ) was added and evaporated with heating ( $\mathrm{ca} .60^{\circ} \mathrm{C}$ ). This process was repeated three times. The residue was extracted with $\mathrm{H}_{2} \mathrm{O}$ and $\mathrm{CH}_{2} \mathrm{Cl}_{2}$, and the aqueous phase was evaporated. The crude product was purified by reverse phase chromatography on Silica C18 using $\left(\mathrm{H}_{2} \mathrm{O}\right.$, $\mathrm{MeOH})$ as the eluent to give $33 \mathrm{mg}(80 \%)$ of compound 12 as a white foam. $[\alpha]_{\mathrm{D}}^{25}-12.0(c 0.20, \mathrm{MeOH})$. FTIR-ATR (neat, $\mathrm{cm}^{-1}$ ): 3327, 2918, 1668, 1540, 1456, 1387, 1148, 1050, 920, $785 \mathrm{~cm}^{-1}$. ${ }^{1} \mathrm{H}$ NMR (D $\left.{ }_{2} \mathrm{O}, 400 \mathrm{MHz}\right): \delta(\mathrm{ppm}) 7.87(\mathrm{~d}, 1 \mathrm{H}, J=8.0 \mathrm{~Hz}), 6.19$ $(\mathrm{d}, 1 \mathrm{H}, J=8.0 \mathrm{~Hz}), 4.67-4.62(\mathrm{~m}, 1 \mathrm{H}), 3.76-3.70(\mathrm{~m}, 2 \mathrm{H})$, 1.81-1.75 (m, 4H), 1.55-1.48 (m, 2H). ${ }^{13} \mathrm{C}$ NMR $\left(\mathrm{D}_{2} \mathrm{O}\right.$, 100.6 MHz): $\delta$ (ppm) 158.7, 149.4, 146.2, 94.2, 61.7, 58.5, 28.8, $25.4(J=130 \mathrm{~Hz}), 18.3$. HRMS (ESI-TOF) $\mathrm{m} / \mathrm{z}:[\mathrm{M}+\mathrm{Na}]^{+}$calcd for $\mathrm{C}_{9} \mathrm{H}_{16} \mathrm{~N}_{3} \mathrm{NaO}_{5} \mathrm{P}: 300.0725$, found: 300.0733 .

\section{Conflicts of interest}

There are no conflicts to declare.

\section{Acknowledgements}

The authors thank the Ministerio de Economía y Competitividad, Spain (grant DGI CTQ2014-58664-R). M. A. thanks AECI and SS thanks URV for a fellowship. MEC thanks to CONACyTMéxico for a post-doctoral grant.

\section{Notes and references}

1 (a) E. De Clercq, Collect. Czech. Chem. Commun., 2011, 76, 480; (b) M. Krecmerova, in Herpesviridae-A Look into This Unique Family of Viruses, ed. G. D. Magel and S. Tyring, INTECH, 2012, ch. 11, p. 245; (c) E. De Clercq, Antiviral Res., 2007, 75, 1; (d) E. De Clercq and A. Holy, Nat. Rev. Drug Discovery, 2005, 4, 928; (e) A. Holy, Curr. Pharm. Des., 2003, 9, 2567; $(f)$ A. Holy, in Current Protocols in Nucleic Acid Chemistry, John Wiley and Sons, Unit 14.2, 2005.

2 (a) H.-L. Sun, F. Chen, M.-S. Xie, H.-M. Guo, G.-R. Qu, Y.-M. He and Q.-H. Fan, Org. Lett., 2016, 18, 2260; (b) H.-L. Sun, F. Chen, M.-S. Xie, H.-M. Guo, G.-R. Qu, Y.-M. He and Q.-H. Fan, Org. Lett., 2014, 16, 2014.

3 (a) K. A. Cruickshank, J. Jiricny and C. B. Reese, Tetrahedron Lett., 1984, 25, 681; (b) H. Tanaka, H. Hayakawa, K. Obi and T. Miyasaka, Tetrahedron, 1986, 42, 4187; (c) L. A. Agrofoglio, I. Gillaizeau and Y. Saito, Chem. Rev., 2003, 103, 1875; (d) M. Hamada, V. Roy, T. R. McBrayer, T. Whitaker, C. Urbina-Blanco, S. P. Nolan, J. Balzarini, R. Snoeck, G. Andrei, R. F. Chinazi and L. A. Agrofolio, Eur. J. Med. Chem., 2013, 67, 398.

4 For a recent review about chemical synthesis of acyclic nucleosides see: (a) M.-S. Xie, H.-Y. Niu, G.-R. Qu and H.-M. Guo, Tetrahedron Lett., 2014, 55, 7156; (b) H.-M. Guo, S. Wu, H.-Y. Niu, G. Song and G.-R. Qu, in Chemical 
Synthesis of Nucleoside Analogues, ed. P. Merino, John Wiley and Sons, 2013, p. 103.

5 T. Wei, M.-S. Xie, G.-R. Qu, H.-Y. Niu and H.-M. Gou, Org. Lett., 2014, 16, 900.

6 M. Gandelman and E. N. Jacobsen, Angew. Chem., Int. Ed., 2005, 44, 2393.

7 (a) H.-M. Guo, T.-F. Yuan, H.-Y. Niu, J.-Y. Liu, R.-Z. Mao, D.-Y. Li and G.-R. Qu, Chem. - Eur. J., 2011, 17, 4095;

(b) H. Wu, Z. Q. Tian, L. L. Zhang, Y. D. Huang and Y. M. Wang, Adv. Synth. Catal., 2012, 354, 2977.

8 (a) H.-Y. Niu, C. Du, M.-S. Xie, Y. Wang, Q. Zhang, G.-R. Qu and H.-M. Guo, Chem. Commun., 2015, 51, 3328; (b) F. Amblard, S. P. Nolan, I. Gillaizeau and L. A. Agrofoglio, Tetrahedron Lett., 2003, 44, 9177.

9 L. M. Stanley and J. F. Hartwig, J. Am. Chem. Soc., 2009, 131, 8971.

10 (a) B. M. Trost, R. Madsen, S. G. Guile and B. Brown, J. Am. Chem. Soc., 2000, 122, 5947-5956; (b) B. M. Trost, R. Madsen, S. G. Guile and A. E. H. Elia, Angew. Chem., Int. Ed. Engl., 1996, 35, 1569.

11 (a) B. M. Trost, D. B. Home and M. J. Weltering, Chem. Eur. J., 2006, 12, 6607; (b) J. Llaveria, Y. Díaz, M. I. Matheu and S. Castillon, Org. Lett., 2009, 11, 205-208; (c) J. Llaveria, Y. Díaz, M. I. Matheu and S. Castillon, Eur. J. Org. Chem., 2011, 1514; (d) S. Soriano, M. Azzouz, J. Llaveria, P. Marcé,
M. I. Matheu, Y. Díaz and S. Castillon, J. Org. Chem., 2016, 81, 5217.

12 S. Soriano, M. I. Matheu, Y. Díaz and S. Castillon, Adv. Synth. Catal., 2016, 358, 4057.

13 P. Andrea, G. Giampaolo, P. Ivana, C. Mariolino and N. Giammario, Eur. J. Org. Chem., 2008, 5786.

14 (a) P. R. Hanson and D. S. Stoianova, Tetrahedron Lett., 1998, 39, 3939; (b) P. R. Hanson and D. S. Stoianova, Tetrahedron Lett., 1999, 40, 3297; (c) M. Bujard, V. Gouverneur and C. Mioskowski, J. Org. Chem., 1999, 64, 2119; (d) M. Schuman, M. Trevitt, A. Redd and V. Gouverneur, Angew. Chem., Int. Ed., 2000, 39, 2491.

15 K. Hiroki, D. Topalis, J. Broggi, U. Pradere, V. Roy, S. Berteina-Raboin, P. S. Nolan, D. Deville-Bonne, G. Andrei, R. Snoeck, D. Garin, J. M. Crance and L. A. Agrofolio, Tetrahedron, 2008, 64, 3517.

16 (a) U. Pradère, H. Clavier, V. Roy, S. P. Nolan and L. A. Agrofoglio, Eur. J. Org. Chem., 2011, 7324-7330; (b) A. Montagu, U. Pradére, V. Roy, S. P. Nolan and L. A. Agrofoglio, Tetrahedron, 2001, 67, 5319.

17 T. Tomioka, Y. Yabe, T. Takahashi and T. K. Simmons, J. Org. Chem., 2011, 76, 4669.

18 D. D. Perrin and W. L. F. Armarego, Purification of Laboratory Chemicals, Pergamon Press, Oxford, 3rd edn, 1989. 